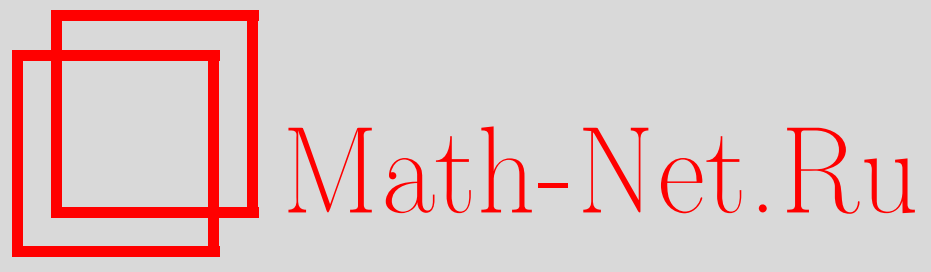

Н. Н. Андреев, Д. К. Мамий, Математический парк, УМН, 2018, том 73, выпуск 4, 188-191

DOI: https://doi.org/10.4213/rm9842

Использование Общероссийского математического портала Math-Net.Ru подразумевает, что вы прочитали и согласны с пользовательским соглашением http://www . mathnet.ru/rus/agreement

Параметры загрузки:

IP: 18.209 .158 .208

26 апреля 2023 г., 14:36:30

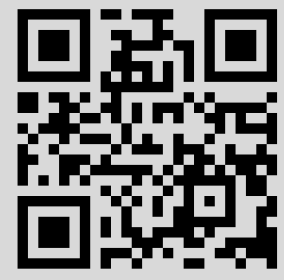




\section{Математический парк}

Первый в России (а по отзывам экспертов - и в мире) математический музей под открытым небом "Математический парк" открылся в последний день весны 2018 г. в столице Республики Адыгея городе Майкопе.

Математический парк - вписанная в городское пространство коллекция арт-объектов, наглядно представляющих математические фигуры и их свойства, математические факты и теоремы. Целью проекта является популяризация математики: мотивация молодёжи к занятиям математикой, пробуждение интереса к ней у взрослых.

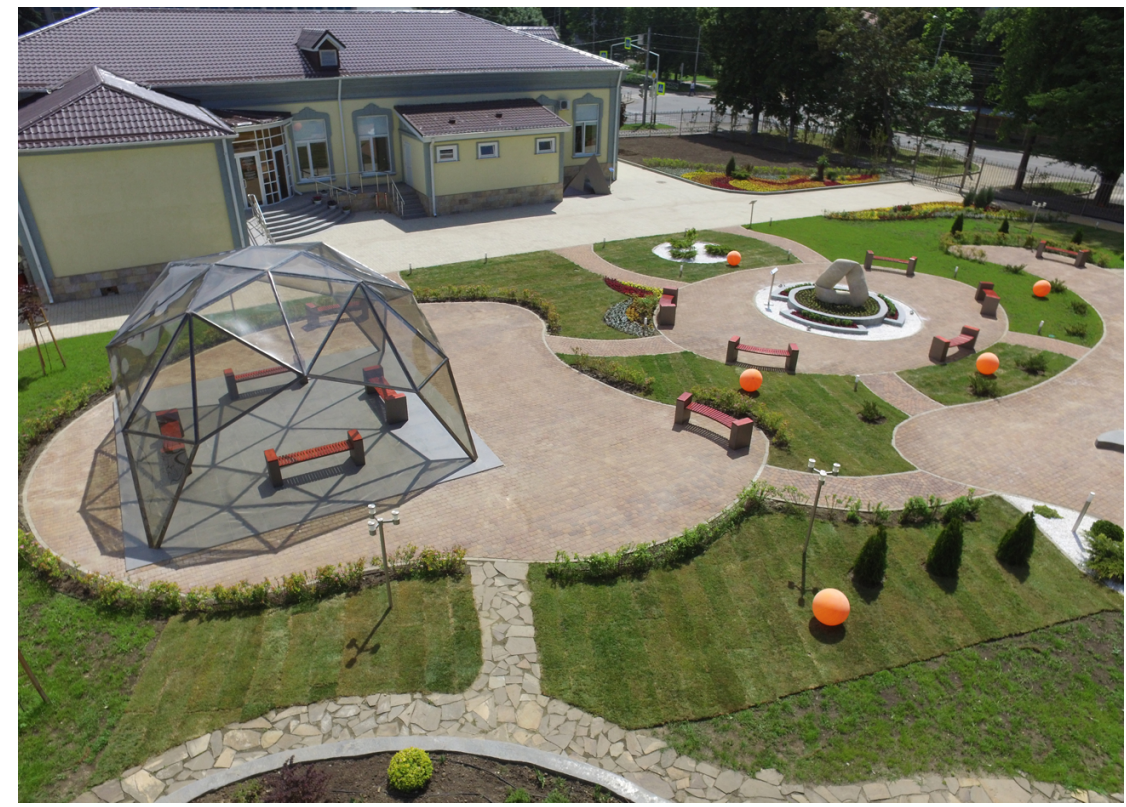

Задача популяризации математики имеет первостепенное значение в современном мире - как для развития самого общества, так и для развития науки. В частности, это один из пунктов Устава Российской академии наук, и руководство РАН уделяет ей большое внимание.

Экспонаты парка являются мощным средством привлечения внимания к математике. Отличительная российская черта популяризации науки - глубина знаний, сообщаемых после захвата внимания. Поэтому рядом с каждым объектом расположена табличка, объясняющая математическую составляющую объекта на первом, начальном уровне. Заинтересовавшийся человек может тут же, отсканировав QR-код со своего мобильного телефона, попасть на сайт парка в интернете http://museum.adygmath.ru, где на странице каждого экспоната представлено уже более глубокое объяснение соответствующей тематики и даны ссылки для дальнейшего изучения.

DOI: https://doi.org/10.4213/rm9842 
Совершим небольшую прогулку по части Математического парка.

Красные дорожки во дворике Республиканской естественно-математической школы (РЕМШ), на базе которой создан парк, - ландшафтное воплощение знаменитой задачи Леонарда Эйлера о семи Кёнигсбергских мостах, а беседка, выполненная из треугольников, символизирует триангуляцию поверхностей.

Лист Мёбиуса, являющийся логотипом РЕМШ, выполнен из доломита. На его односторонней поверхности выгравированы три изображения всемирно известных археологических находок, най-

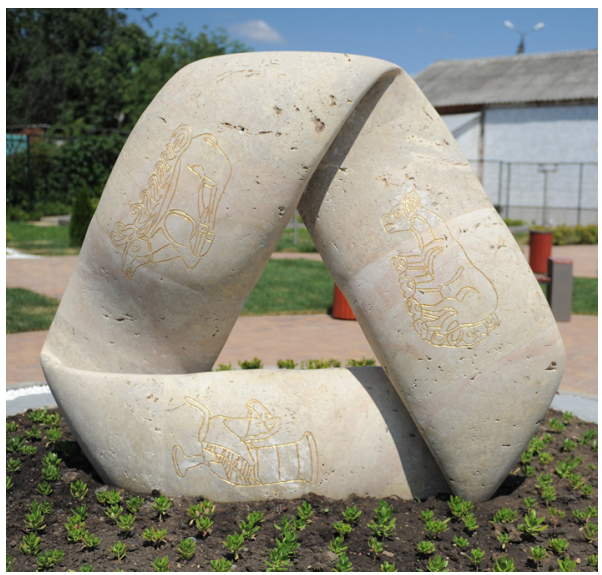
денных в курганах Адыгеи: серебряный сосуд ритон, имеющий скульптурное окончание в виде крылатого коня Пегаса, золотая бляха-накладка в виде лежащего оленя, нащитная золотая бляха в виде пантеры. Указанные находки свидетельствуют о богатейшем историко-культурном наследии Адыгеи. Летящий олень, найденный в кургане в городе Майкопе, относится к древнейшей из известных культур, существовавших на территории современной России (конец IV-середина II тыс. до н. э.). Эта культура получила название майкопской.
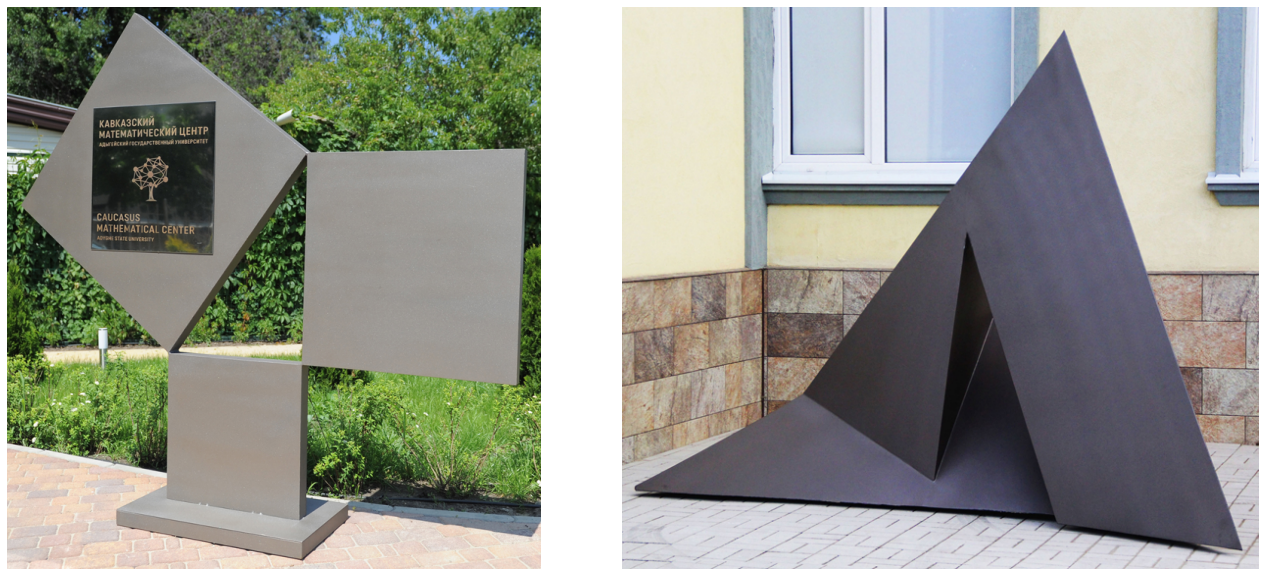

Классическая геометрическая интерпретация теоремы Пифагора, с квадратами, построенными на сторонах, выбрана символом Математического парка. Несмотря на то что существует множество реализаций (с переливанием воды, пересыпанием песка; не с квадратами, а с любыми подобными фигурами, построенными на сторонах; головоломка, представленная в коллекции математических экспонатов лаборатории популяризации и пропаганды математики Математического института им. В. А. Стеклова РАН), простейшая минималистическая конструкция смотрится завораживающе.

Многограник Силашши (Lajos Szilassi), обнаруженный им в 1977 г., - единственный, кроме тетраэдра, известный многогранник, у которого любые две грани имеют общее ребро.

Одним из арт-объектов парка является однополостный гиперболоид вращения поверхность второго порядка, через каждую точку которой проходят две прямые. Это свойство было использовано известным российским инженером почётным членом 
АН СССР В. Г. Шуховым для постройки башен. Владимир Григорьевич спроектировал и построил в России более двухсот гиперболоидных водонапорных башен. При этом каждый проект был уникален - выполнение технических требований соединялось с архитектурной привязкой к местности. Первая такая конструкция была представлена на Всероссийской промышленной и художественной выставке, проходившей в 1896 г. в Нижнем Новгороде. А одна из сохранившихся водонапорных башен расположена в Краснодаре, в аэропорт которого прилетают гости Майкопа.

На огромном баннере "Стена геометрии" приведено более 250 чертежей из книги А. В. Акопяна "Геометрия в картинках" - сборника теорем классической геометрии, сформулированных в виде картинок. Они нарисованы таким образом, что не требуют слов, текста - соответствующие утверждения можно восстановить (и попробовать доказать), рассматривая приведённые картинки!
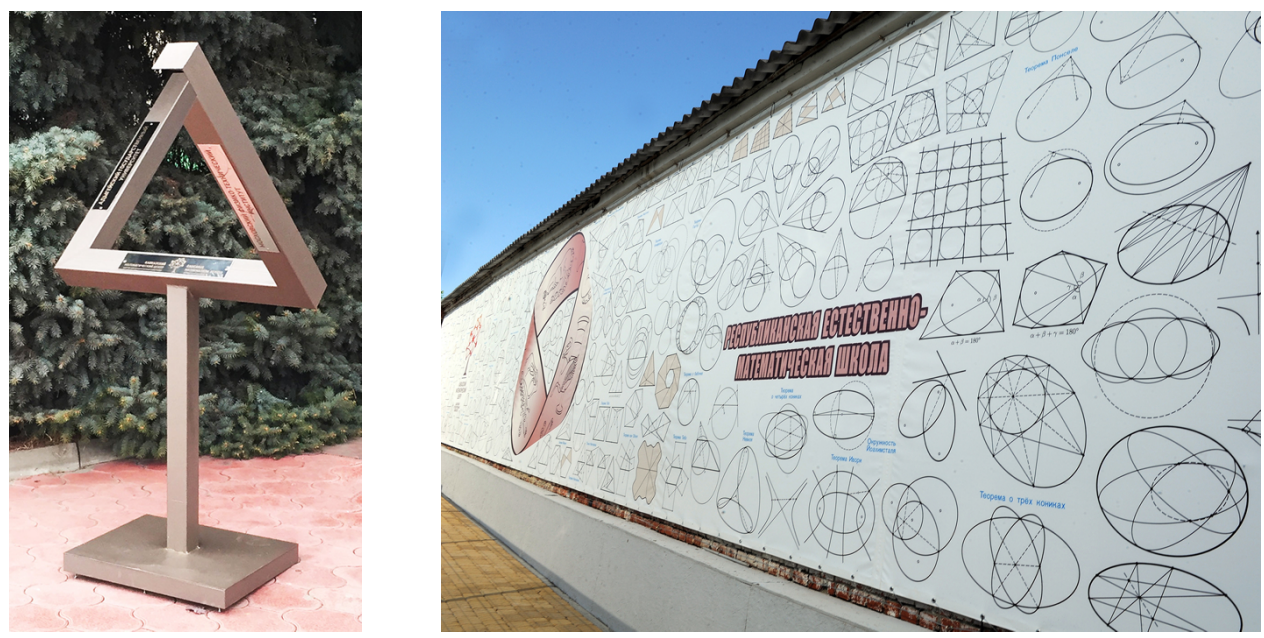

Перед входом в Главный корпус Адыгейского государственного университета отличным стоппером прохожих служит выполненный из металла невозможный треугольник Пенроуза. И даже табличка на входе в помещения КМЦ АГУ несёт в себе математическую составляющую. Центральная её часть - скатерть Улама (Stanisław Ulam), открытая им в 1963 г. и графически представляющая появление простых чисел среди натуральных, записанных по спирали.

Но прервём нашу прогулку. Как говорится - лучше один раз увидеть... Приезжайте в Майкоп! Ведь неслучайно первый математический музей под открытым небом появился именно здесь - в республике уже много лет работа со школьниками ведётся на уникально высоком уровне.

Республиканская естественно-математическая школа, на базе которой создан парк, вот уже 20 лет готовит лучших школьников из Республики Адыгея до уровня призёров и победителей всероссийской олимпиады по различным предметам. Около 50 выпускников ежегодно поступают в лучшие столичные вузы. РЕМШ организует целый ряд значимых межрегиональных, российских и международных образовательных проектов: Южная математическая смена в Образовательном центре "Сириус" (https://sochisirius.ru/obuchenie/nauka/smena24); Всероссийская смена "Юный математик" и Южный математический турнир во Всероссийском детском центре "Орлёнок" (http://www.adygmath.ru); Летняя математическая школа в Адыгее, проводимая ежегодно с 1995 г.; Кавказская математическая олимпиада (http://www.adygmath.ru).

В проектах математической направленности, реализуемых РЕМШ, принимают участие школьники из 48 регионов России, включая все регионы Южного и Северо- 
Кавказского федеральных округов. А идея Кавказской математической олимпиады - подружить на почве интереса к математике детей не только российской части Кавказа, но и всех других стран региона ${ }^{1}$. Преподавателями и членами жюри проводимых мероприятий являются лучшие российские педагоги, многие из которых представляют ведущие вузы и являются членами Центральной предметно-методической комиссии Всероссийской олимпиады школьников по математике.

Ещё одним участником проекта "Математический парк" является Кавказский математический центр на базе Адыгейского государственного университета - недавно созданный при участии научной команды Московского физико-технического института региональный научно-образовательный центр, призванный обеспечить, опираясь на достижения республики в обучении школьников, уникальное для российских регионов качество образования высшей ступени и высокий уровень научных исследований. Конечная цель - создание конкурентной системы подготовки математиков, которая была бы привлекательна для выпускников школ и обеспечивала бы регионы Юга России специалистами и исследователями высокой квалификации. Выстроенную РЕМШ сеть взаимодействия со школами в Адыгее и регионах Юга России Центр планирует трансформировать в систему опорных школ, посредством которой он сможет организовать регулярную деятельность по популяризации математики среди школьников.

Имеющиеся в этой области заделы позволяют надеяться, что удастся реализовать одну из основных задач Центра - сформировать в Республике Адыгея и регионах Юга России культ математики и "моду" на математическое образование.

В проекте "Математический парк" не обошлось без ещё одного участника - Математического института им. В. А. Стеклова Российской академии наук и его лаборатории популяризации и пропаганды математики.

В церемонии открытия Математического парка приняли участие вице-президент РАН академик Валерий Васильевич Козлов, некогда "узаконивший" в Математическом институте им. В. А. Стеклова Российской академии наук направление популяризации математики, и Глава Республики Адыгея Мурат Каральбиевич Кумпилов, поддержавший идею создания парка. Ими были посажены первые деревца кленовой аллеи.

В реализации идеи парка приняли участие Ася Еутых, член Союза художников России, народный художник Республики Адыгея, и Татьяна Ваганова, дизайнер, член Союза художников России. Экспонаты из металла выполнены Константином Богдановым, каменная реализация листа Мёбиуса - компанией "S-Камень", руководимой Сальбием и Анзором Киковыми, а дизайн и программирование интернет-сайта - Романом Кокшаровым.

Математический парк будет расширяться и выйдет за границы Республиканской естественно-математической школы и Адыгейского государственного университета. В Адыгее планируют размещение математических арт-объектов по всему городскому пространству Майкопа. Приглашаем и другие города присоединиться к участию в проекте!

Н. Н. Андреев, Д. К. Мамий

${ }^{1}$ cm.: D. Mamiy, "Caucasus mathematical olympiad", Eur. Math. Soc. Newsletter, 2017, June, $55-56$ 